\title{
’88年タイ南部での豪雨災害の原因についての考察
}

\section{A Study on the Causes of Debris Flow Damage '88 in Southern Thailand}

\author{
オーケー・ローゼンクウィスト*，村井俊治* \\ 越智士郎*, スーウィット・ビブンセート**
}

\begin{abstract}
This report deals with the influence of deforestation and shifting cultivation on the occurrence of landslides in an area in southern Thailand which in 1988 suffered from intensive rainfall and severe flooding.

LANDSAT and SPOT data have been used in combination with a DTM over the area in an effort to calculate a figure of the rate of defotestation, to estimate the extent of the damage of the landslides in the mountainous areas as well as to search for potential relationships between the landslides, the landcover and the slope inclination. Other factors, such as the amount of rain at the time and the geology in the area, have also been considered briefly.
\end{abstract}

\section{1.はじめに}

1988年夕イ湾中央で発生した低気圧は極めて激し い降雨をタイ南部の各県にもたらした。中でもナコ ン・シ・タマラット県のピプン地区では 4 日間の連続 雨量が $1000 \mathrm{~mm}$ を越え，最大日雨量も $447 \mathrm{~mm}$ を記録 した。ピプン地区は四方を山に囲まれ，北側の急峻な カオルアン山脈から流れる2つの大きな河川（カトゥ ン川，ピプン川）の平野部への出口に位置している。 この降雨により山間部では斜面崩壊現象が次々と発 生し，下流の村は $3 ， 4$ メートル，ひどいところでは 6 メートルもの土砂に埋まり，この土石流災害によっ て，多数の人命を失う大災害となった。

ピプン地区の森林は'80年代に入るまでは極めて良 好な自然状態を保っていた。' 80 年代に入り政府により この地域での木材生産や林地の有効利用が促進され たが，地元住民による適地選定を無視した無計画な森 林伐採によって森林破壊と, 耕地, 荒地化が進む結果 となった。さらに’80年代半ばからの「ゴムブーム」が それに拍車をかけ，自然林のかなりが伐採されゴム農

* 東京大学生産技術研究所

$* *$ 夕イ国立研究評議会

「写真測量とリモートセンシング」Vol. 29,No. 4, 1990
園に転換されたが，ゴムの木の生育に適さなかった急 斜面地はそのまま草地や裸地として放置されていた。

'88年豪雨で発生したこの地域の洪水被害並びに斜 面崩壊の原因の一つが自然林の減少であると考えら れているのは，次のような理由による。まずゴムの木 の根は自然林を構成する他の樹木に比べて非常に浅 くしか張ることがないため土壌を固定する能力が少 ないことである。特にこの傾向は急斜面ほど強く現わ れる。また保水能力についても，下草のほとんどがな い（あっても草本や潅木程度）ゴム林土壌は，さまさ まな種，サイズ，形状の植生より構成される自然林に 比べ劣っていることがあげられる。更に斜面崩壊を誘 発する要素として斜面傾斜，降雨，地質等が考之られ るが, 本論では森林の斜面崩壊抑制に与える影響に着 目し, 衛生データとDTMより得られる情報をもとに 今回の災害原因を解析し，検討した。

\section{2.土地被覆変化}

\section{1 前 処 理}

土地被覆の変化に関する調査は異なる二時期の衛 星データ（'84年 4 月12日撮影のランドサット MSS 画 像と 4 年後の' 88 年 3 月 30 日撮影のランドサット TM 画像）を用い行った。この 4 年間で植生から非植生あ るいはその逆への変化の抽出には主成分分析法を用 
いた。また，それぞれの画像での土地被覆分類には最 尤法を用いた。解析対象範囲として斜面崩壊が著し く，下流域にも多大な洪水被害をもたらしたピプン流 域とカトゥン流域をカバーする範井 $(24 \mathrm{~km} \times 24 \mathrm{~km})$ を選んだ（図 1 参照）。

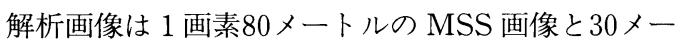
トルの TM 画像を使用したため, 重ね合わせが可能 になるよう 1 画素50メートルに統一し, 幾何補正後再 配列を行った。また88年 TM 画像中には若干雲が含 まれるため主成分分析を行う場合には雲の部分にマ スク処理を施した。また主成分分析及び最尤法では山 間部での土地利用のみに注目したため標高100メート ル以下の平野部をのぞいて解析を行った。

\section{2 主成分分析}

センサー特性の似た MSS 1，2，4 バンドと TM $2 ， 3 ， 4$ バンドの計 6 バンドを用いて主成分分析を 行った。その結果第 3 主成分が二時期の反射強度の差 すなわち二時期の土地被覆の変化と考之られた(1)。こ の第 3 主成分のある上限值より高い值を持った画素 は植生から非植生に変化した地点であり逆にある下 限值より低い值を持つ画素は非植生から植生に変化 したことになるため, 現地調査等によって適当な上限 值, 下限值を決定し土地被覆の変化地の抽出を行っ た。その結果, 1500へクタールが植生から非植生に変 化し，200へクタールが非植生から植生に変化したこ とになる。しかし主成分分析は反射強度が変化した事 象のみに注目しているため植生の質の変化 (たとえば 熱帯林からゴム農園に変化した場合) を正確に知るこ とができない。図一 2 は主成分分析法によって得られ た変化抽出を示している。植生から非植生への変化 （開墾地）が村落に近い山腹斜面や谷沿いに集中して
いることがわかる。

\section{3 土地被覆分類}

土地被覆の詳しい変化内容を調べるため最尤法に よって 84 年 MSS 画像と88年 TM 画像についてそれ ぞれ土地被覆分類を行った(表一 1$)$ 。雲などによって 16パーセントが未分類として解析対象より除外され たが， 4 年間で約 400 ヘクールの自然熱帯林が消滅 し，裸地またはゴム林へ転換したことになる。

\section{3 ．斜面崩壊原因の解析}

'88年の豪雨で斜面崩壊がどのような原因で発生し たかを解明することが, 将来同じような災害の予測, 予防を行うために重要である。そこでまず土地被覆に 関して考察を行い，ついで斜面傾斜，降雨，地質につ いて考察を加える。

使用した衛生データは'88年 TM (災害前) と'89年 2 月 9 日 (災害後) 撮影の SPOT カラ一画像であり, 画 素サイズ $25 \mathrm{~m}$ で統一するため幾何補正後再配列を 行った。さらに 5 万分の 1 地形図より数值化標高デー

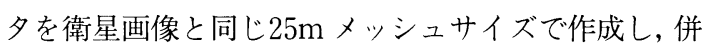
せて利用した。図 3 (a)は同地区の SPOT 画像であり， (b)は DTM を組み合わせた鳥瞰画図である。

\section{1 土地被覆分類および斜面崩壊状況}

災害前の TM 画像より土地被覆を次の 5 つのカテ ゴリーに分類した。

(1) 裸 地一植生の存在しない地区

(2) 疎植生一植生が認められるものの表土が露出 している地区

おもにゴムの幼樹を植林した場所に

表 1 最尤法による土地被覆分類（'84.4 .12MSS と'88. 3.30 TM）

\begin{tabular}{|l|c|c|c|c|}
\hline Land Type & MSS 1984 & TM 1988 & CHANGE & $\begin{array}{c}\text { RATIO } \\
\text { ('88/'84) }\end{array}$ \\
\hline Bare Soil & 560 & 1610 & 1050 & 2.87 \\
\hline Sparse Veg. & 4930 & 3460 & -1470 & 0.70 \\
\hline Rubber & 6430 & 10850 & 4420 & 1.68 \\
\hline Tropical forest & 25200 & 21200 & -4000 & 0.84 \\
\hline Unclassified & 6520 & 6520 & - & - \\
\hline Total & 43640 & 43640 & - & - \\
\hline
\end{tabular}




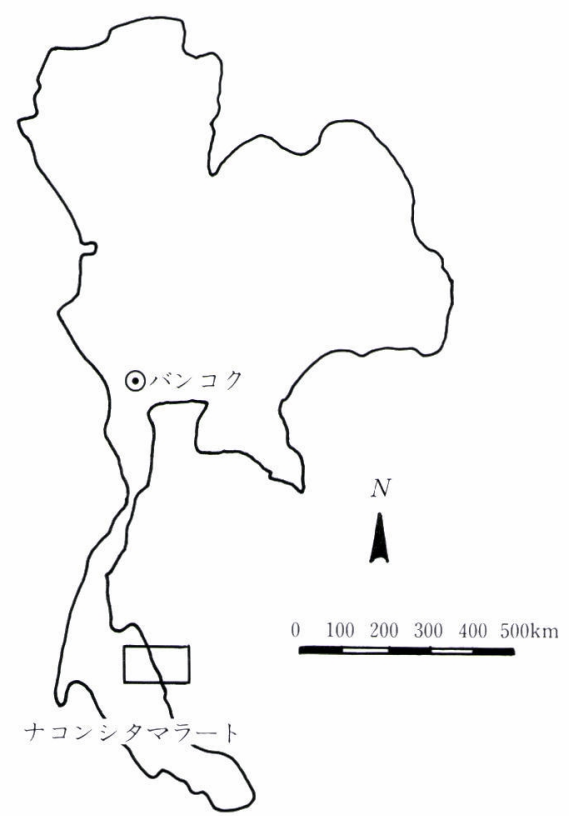

(a) 被災地域

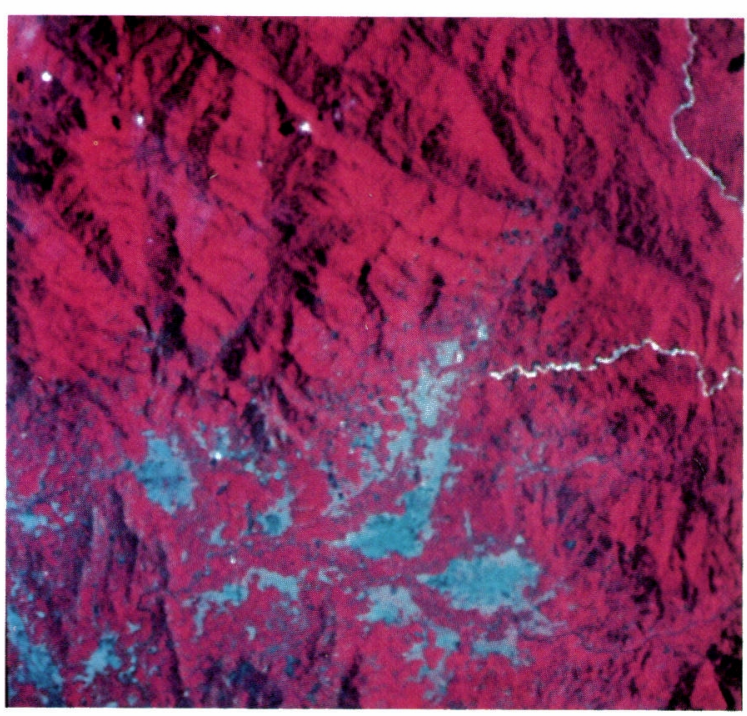

(b) MSS 画像（1984年 4 月12日撮影）

図 1 洪水被害調査地域

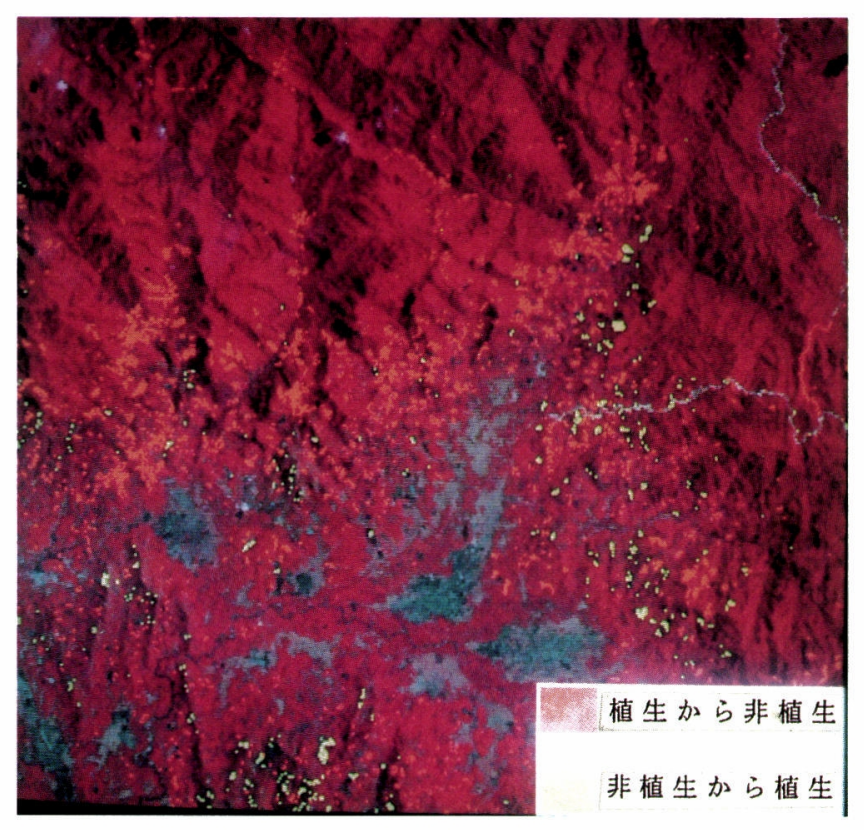

図 2 主成分分析による植生から非植生への变化 (1984年から1988年の 4 年間) 


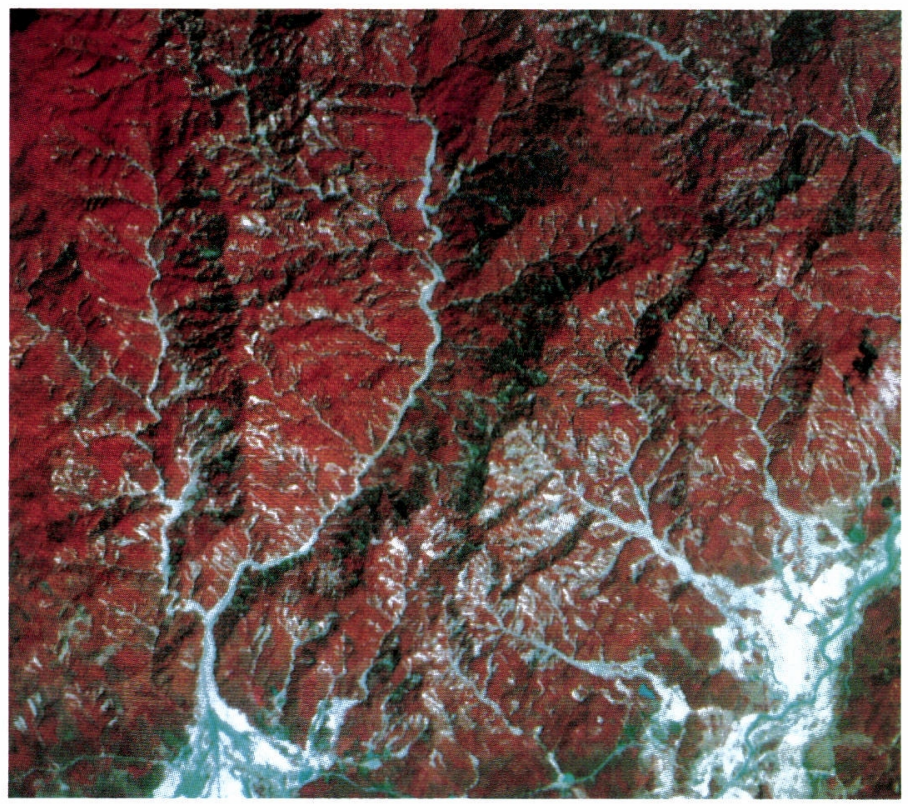

(a) SPOT 画像

1989年 2 月 9 日

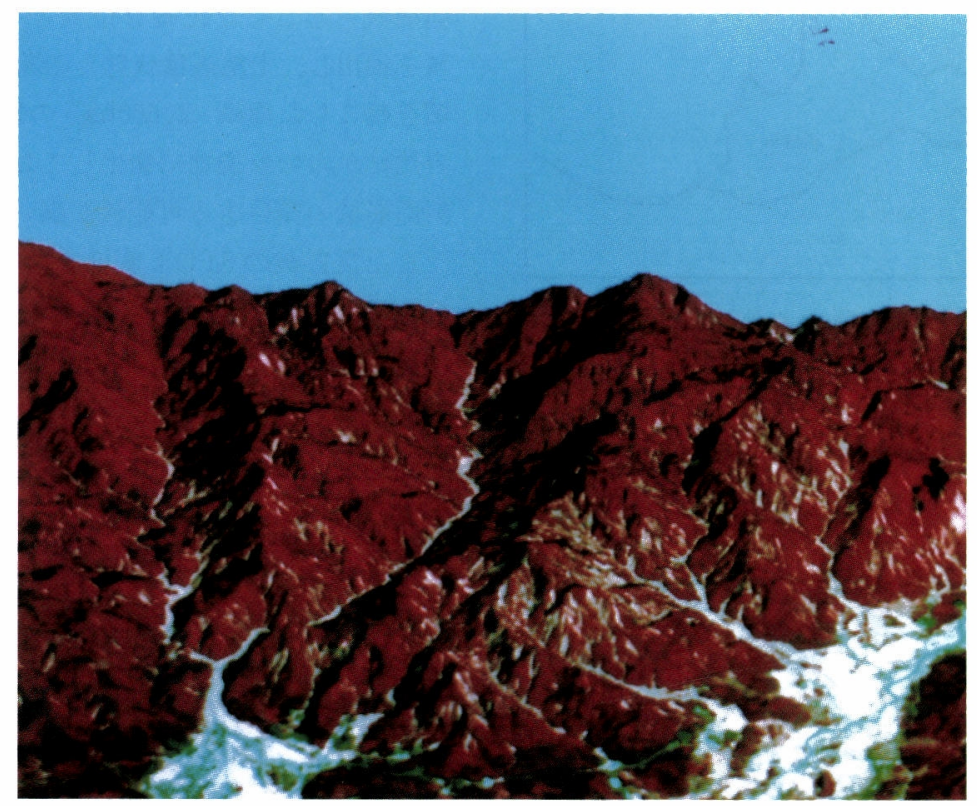

(b) 鳥かん画像

図 3 斜面崩壊をとらえた SPOT 画像 
表 2 洪水直前の土地被覆（1988.3）と斜面崩壊の頻度（1988.11）

\begin{tabular}{|l|c|r|c|c|c|}
\hline \multicolumn{1}{|c|}{ Land type } & $\begin{array}{c}\text { Total } \\
\text { Area (he) }\end{array}$ & $\%$ & $\begin{array}{c}\text { Landslides } \\
\text { Area (ha) }\end{array}$ & $\%$ & $\begin{array}{c}\text { Landslide } \\
\text { freq (\%) }\end{array}$ \\
\hline Bare soli & 1610 & 4 & 190 & 7 & 11.8 \\
\hline Sparse vegetation & 3460 & 8 & 385 & 15 & 11.1 \\
\hline Rubber & 10850 & 25 & 770 & 29 & 7.1 \\
\hline Tropical forest & 21200 & 48 & 960 & 36 & 4.5 \\
\hline Unclassified & 6520 & 15 & 340 & 13 & 5.2 \\
\hline Total & 43640 & 100 & 2645 & 100 & 6.1 \\
\hline
\end{tabular}

みられる

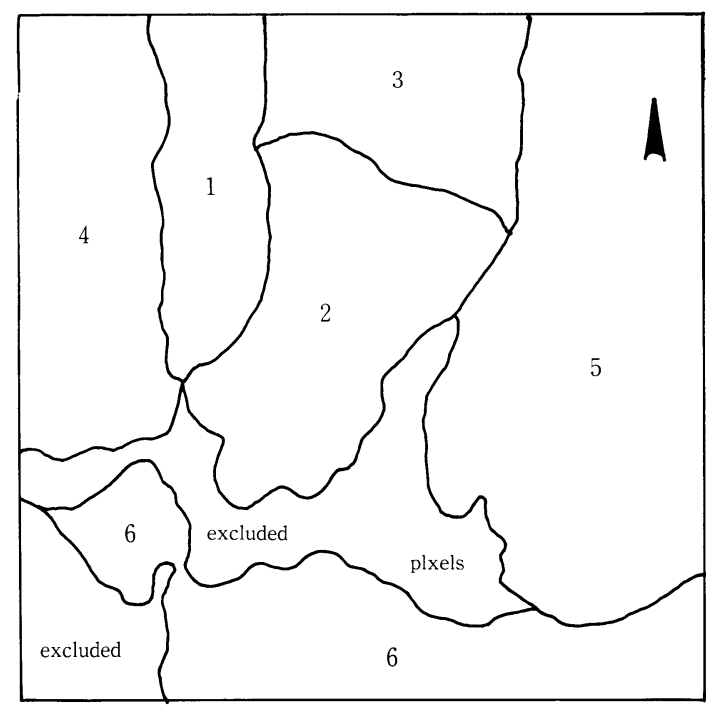

図 46 地区への分割
(3) ゴム林一十分に生育したゴム林

(4) 熱帯林一人為的影響をほとんど受けていない 自然林

(5) 未分類一雲及び陰

表 2 に示すように, 熱帯林が48\%(21,200ha), 裸地, 希薄な植生, ゴム農園等自然林からの転換地 (開墾地) と考えられる地域が37\% (15,920ha)，未分類地域が $15 \%(6,520 \mathrm{ha})$ となった。

一方, 災害後のSPOT カラー画像の判読により斜 面崩壊を起こした正確な位置とその災害を受けた地 域を抽出し, 土地被覆状態との関係を調べた。斜面崩 壊を起こした面積 $(2,600 \mathrm{ha})$ の約半分 $(1,345 \mathrm{ha})$ は 自然林からの転換地に発生しており, 自然林に比べて 斜面崩壊の発生する可能性が高いことがわかる。

また災害後のSPOT 画像より斜面崩壊現象が全て の山地斜面で均等に発生していないことが判読でき たので, 谷線, あるいは稜線によって解析対象範囲を 図 4 に示すように, 大きく6つの地区にわけ各地区で

表 3 地区毎の斜面崩壤頻度（カッコ内：全地域に対する\%）

\begin{tabular}{|c|c|c|c|c|c|c|}
\hline & $\begin{array}{l}\text { Bare } \\
\text { Soil }\end{array}$ & $\begin{array}{l}\text { Sparse } \\
\text { Veg. }\end{array}$ & Rubber & $\begin{array}{l}\text { Tropical } \\
\text { forest }\end{array}$ & Unclass & Average \\
\hline & $\% \quad(\%)$ & $\% \quad(\%)$ & $\% \quad(\%)$ & $\% \quad(\%)$ & $\% \quad(\%)$ & $\% \quad(\%)$ \\
\hline (1) Kathun & $27 \quad(3)$ & $30 \quad(4)$ & $21 \quad(1)$ & $(55)$ & (23) & $10.9 \quad(10)$ \\
\hline (2) Huai-ko & $19 \quad(6)$ & $23 \quad(11)$ & $16 \quad(31)$ & $12 \quad(39)$ & $7 \quad(13)$ & $14.0 \quad(16)$ \\
\hline (3) North & $14 \quad(1)$ & $10 \quad(2)$ & (13) & $(37)$ & $4 \quad(47)$ & $5.5 \quad(11)$ \\
\hline (4) West & $12 \quad(5)$ & $8 \quad(8)$ & $4 \quad(17)$ & (54) & $6 \quad(16)$ & $3.9 \quad(16)$ \\
\hline (5) East & $8 \quad(3)$ & $10 \quad(6)$ & $6 \quad(23)$ & $(64)$ & $3 \quad(4)$ & $3.7 \quad(34)$ \\
\hline (6) South & $2 \quad(5)$ & $2 \quad(17)$ & $2 \quad(52)$ & $(20)$ & $3 \quad(6)$ & $2.2 \quad(13)$ \\
\hline Total area & $11.8(4)$ & $11.1(8)$ & $7.1(25)$ & $4.5(49)$ & $5.2(16)$ & $6.1(100)$ \\
\hline
\end{tabular}


の土地被覆と斜面崩壊状況を調べた。表 3 は 6 つの地 区における土地被覆と斜面崩壊状況を調べたもので ある。

Kathun 地区(1)と Huai-ko 地区(2)は他の 4 つの地 区と比較して斜面崩壊の頻度が高く $(10.9 \%$, $14.0 \%)$ ，この 2 つの地区はまた裸地，希薄な植生，ゴ 么農園の占める割合も他の 4 地区に比べて高い。西地 区(4), 東地区(5)では斜面崩壊の頻度はかなり低く，南 地区(6)はもっとも低い。南地区で開墾率が高いにも関 わらず崩壊頻度がきわめて低いのは後述するように 地質要因によると考えられる。

植生の密度が減少するのに従い斜面崩壊発生頻度 が増加することが明らかになったが，一方で崩壊の $36 \%$ が自然状態を保った熱帯林地区で発生している ことより，土地被覆以外にも斜面崩壊を誘発する要因 を考慮する必要がある。

\section{2 斜面 傾 斜}

土地被覆とともに斜面傾斜度の影響を調べるため, 88年 TM 画像 (災害前) 加求めた土地被覆分類四と DTM より求められる傾斜角 $5^{\circ}$ 間隔 $\left(3^{\circ} \sim 8^{\circ}, \cdots, 43^{\circ}\right.$ $\left.\sim 48^{\circ}\right)$ の傾斜斜面困, さらに災害後の SPOT 画像より 判読された斜面崩壊地分布図を重ね合わせることで 土地被覆と, 斜面傾斜の関係を求めた。各土地被覆・ 傾斜の増加に従い斜面崩壊発生頻度を調べグラフに 表した(図一 5 )。斜面傾斜の増加に従い斜面崩壊発生 率も増加するが, 植生の密度が高いほど斜面崩壊に対 する抵抗力が大きくなっていることが判明した。特に
裸地（Bare Soil）及び疎植生（Sparse Veg.）では傾 斜が $38^{\circ}$ 以上になると熱帯林の 2 倍以上の頻度の斜面 崩壊が起きている。

\section{3 他の要 因}

\section{3 .1 降雨}

斜面崩壊を引き起こした直接的な原因は紛れもな く豪雨である。従って今回の降雨が過去にどの程度の 頻度で起こっているのか，それともまったく異常な豪 雨であったのかを知ることは重要である。

タイの気候には大きな 2 つ季節がある。ひとつは 5 月中旬から 9 月にかけての南西モンスーン期であ り，もうひとつは11月から 3 月中旬にかけての北西モ ンスーン期である。前者が夕イ全土に中強度の豪雨を もたらすのに比べて, 後者は南部地方のみに強度の降 雨をもたらし，他の地方は乾燥した気候となる(2)。し たがって今回'88年11月の豪雨は北西モンスーン期に よく見られるように，タイ湾で発生する低気圧がもた らす豪雨であった。ただし問題となる降雨強度につい ては，もっとも被害の大きかったピプン地区に雨量の 観測施設がないために不明であるが, 表 4 に示すよう

\section{ナコンシラマラート観測所における最大(日)雨量}

記録 $(1951 \sim 1988)$

\begin{tabular}{|c|l|l|l|c|}
\hline Year & $\begin{array}{c}\text { lday (date) } \\
(\mathrm{mm})\end{array}$ & 2days & 3days & 4days \\
\hline 1951 & 238.6 & 398.2 & 626.8 & 791.2 \\
\hline 1975 & $433.3(5 / 1)$ & 686.7 & 775.9 & 845.6 \\
\hline 1776 & $414.0(23 / 11)$ & 461.9 & 491.4 & 587.6 \\
\hline 1988 & $447.8(21 / 11)$ & 734.7 & 885.4 & 1022.6 \\
\hline
\end{tabular}

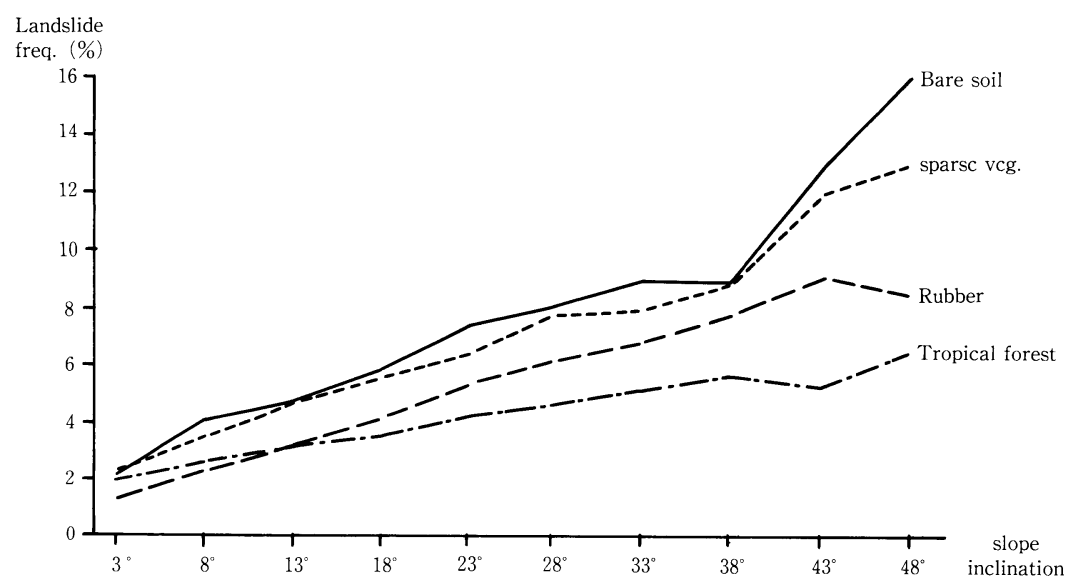

図 5 斜面傾斜と 斜面崩壊の関係 
に, $40 \mathrm{~km}$ 離れたナコン・シ・タマラット観測所の雨 量デー夕によると，1950年からの観測データの中では 連続雨量, 最大日雨量共に'88年の災害時に最大值を記 録している。夕イ気象局が1951年から87年までのデー 夕を用いて, 今回の降雨が起こる確立を求めたとこ ろ, $448 \mathrm{~m}$ の日雨量で150年, 4 日間の連続雨量が 1,022 $\mathrm{m}$ となると 350 年のリターンピリオドであることがわ かった (3)。つまり88年の災害は異常豪雨による災害で あると考えることもできる。しかし，1975年の降雨パ ターンは今回と類似しており, 今回ほどではないにし ても，斜面災害の発生する可能性は十分あったはずで ある。にもかかわらず斜面災害が発生しなかったのは 山間部が良好な自然林を保っていたからではないか と考えられる。

\section{3 .2 地}

質

さらに斜面崩壊の主要な原因と考えられるのは地 質である。今回斜面崩壊が発生したカオルアン山脈は 主に花崗岩, 部分的に砂岩の岩盤より形成され, 平坦 部では堆積層, 崩積層 (主に重力によって斜面または 崖のふもとに運ばれた，ゆるく粘着性のない堆積層） がひろがっている。山間部での花崗岩と, 砂とが入り 交じった非常に粗い土㙵を花崗岩の岩盤上に形成し ている。その上に薄く肥沃な土壤が形成されている。

図 6 は崩壊地の断面を示しており，ゴムの木の根が浅 いことがわかる。

降雨によって，表層土壤は水分を十分に含み，それ が砂状土壤である場合には非常に滑り易い不安な状 態となる。この傾向は斜面が急であるほど強く現われ るので, 斜面崩壊の危険度は急激に増加する。

地質図より(1)〜(3)地区の地質はほぼ花崗岩であり,

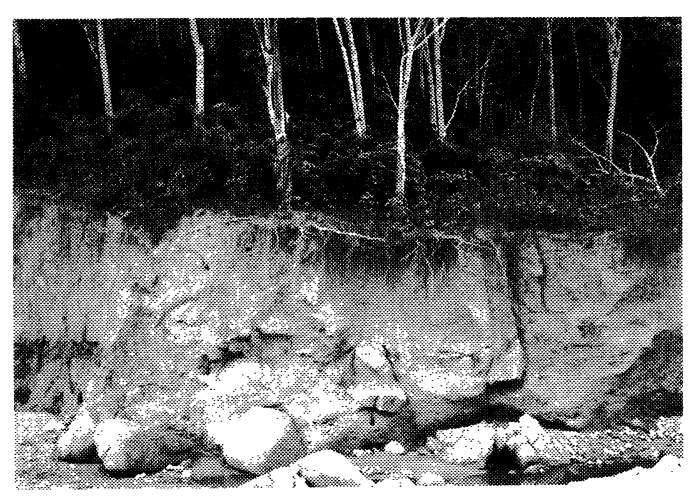

図 6 崩壊地の表面断面
もっとも災害の危険度の高い地質であることがわ かった。一方, 崩壊頻度のより低い東地区(5)は, 花崗 岩と砂岩がほぼ同じ割合で構成される地質であるが, 同程度の発生頻度の低さを示す西地区(4)の地質は純 粋な花崗岩質である。発生頻度の最も低い南地区(6)の 地質は純粋な砂岩質である。

地質が斜面崩壊の要因の一つであることは周知の ことであり,開墾率の高い南地区(6)でも斜面崩壊の発 生頻度が少ないことも地質条件を考慮すれば説明で きる。しかし，地質と斜面崩壊の危険度をはっきり対 応づけるためにはさらにくわしい調査が必要と思わ れる。著者らの現地調査によれば，植生の成育環境と しての土哄条件を含め表層地質が極めて重要である ことが確かめられた。

\section{4. 結 論}

土地被覆の変化抽出によって’84年から'88年の 4 年 間に4,000ha 熱带林が伐採され，そのほとんどがゴム 農園や裸地となっていたことがわかった。また大部分 の開墾地が山間部でも村落から近いなだらかな斜面 や，谷沿いに集中していることが判明した。

斜面崩壊地調查により, 解析対象範囲全体で, 2,600 haの面積が斜面崩壊を起こしたことがわかった。そ の $1 / 2$ が開墾地で起こり, $1 / 3$ が熱帯林地域で起こり, 残 りが末分類地域で起こっている。これらのことから斜 面崩壊が土地被覆状態に影響を受け発生し, 植生被覆 度の大小が斜面崩壊に対する抵抗力の大小に反映し ていることが判明した。つり植生被覆度の高い熱帯林 で斜面崩壊に対する抵抗力が強く, 裸地では最も弱 い。

斜面傾斜の大小が斜面崩壊の発生に影響を持って いることを確認した。急斜面になるほど植生被覆度の 大小が抵抗力の大小に影響することが判明した。

表層地質が斜面崩壊の重要な要因であることを確 認したが, 地質カテゴリーと危険度の対応づけを決定 するためには更に詳しい調査が必要である。

\section{5 . 提言}

将来同じような災害が起こらないように，その対策 をたてることが重要である。そのために何をなすべき か提言を行う。 
まずこの地域での森林伐採を中止す。夕イ国政府は すでに国内の全ての伐採を禁止しているが，この政策 を徹底して守っていく必要がある。しかし，現実には 違法伐採が行われ，媣刻な問題となっている。そのた めに地元住民に森林伐採，そしてゴム農園への転換が 災害発生の重大な原因となっていることを理解して もらうことが必要である。特に風化花崗岩の急斜面の 山岳部は自然林のまま保全すべきである。

この土石流災害の後, タイ王室灌溉局では将来下流 の平野部に今回同様の土石流被害が及ばぬよう山麓 部に大規模な貯水多ムの建設を計画している(4)。しか しこのダムの建設により多くの耕地が水没するため 農民の反対を強く受けている。筆者らは山間部におけ る斜面崩壊の防止対策として日本で伝統的に行われ ている『シガラ』等の山腹砂防工事を行うと共に，山

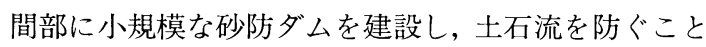
を提言している。

\section{参 考 文 献}

1 ) 村井, 柳田, 宗岡, 1983, LANDSAT 画像を用いた東 京周辺の土地利用変化, 昭和58年日本写真測量学会春期 講演集, P71

2) Arbhabhirama, A. et al, 1987. Thailand Natural Resources Profile. Thailand Development Research Institute.

3) Vongvisessomjai, S., 1989. Rainfall over Southern Thailand and its Flood

4 ) Wieland, M., 1989. Effects of Floods of November 18-23, 1988 in Southern Thailand on Highway Bridge and Large Dams, Asian Institute of Technology, Bangkok, Thialand.

5 ) Richards, Jon A., 1986. Remote Sensing Digital Anaylsis, Springer-Verlag Berlin Heidelberg, ISBNO-387-16007-8

6) Rosenqvist, A. et al, 1989. Forest Change Detection -A Study of the Flooded Area in King Amphoe Phipum, Province of Nakhon Si Thammarat, Thailand, Proc. on the 10th Asian Conferemce on Remote Sensing, Kuala Lunpur, Malaysia, Nov. 23 $-29,1989$ 